\title{
DARAH DAN AIR MATA BEKOR: MENGIMBAU KEMBALI PERISTIWA 6 MAC 1946
}

\author{
Mohamed Ali bin Haniffa
}

\begin{abstract}
This article discusses an incident that occurred on 6 March 1946 at Bekor Village in Kuala Kangsar, Perak. On that morning, Bekor Village was attacked by the communists as a reprisal for not supporting their struggle. A close relationship that had been built over a long period among ethnic groups suddenly turned into a racial confrontation at the end of the war. This relationship that was filled with suspicion transformed into attacks after the withdrawal of Japanese military from Malaya. The feeling of prejudice sparked mutual grudge particularly by the communists towards Malays. An examination of primary and secondary sources showed that the event on 6 March 1946 left a major impact on race relations in Malaya. The sources indicate the British Military Administration failed to handle the situation effectively. The study also found that the incident served as an early catalyst to the rise of Malay nationalism.
\end{abstract}

\section{Pengenalan}

Kolonialisme British dan pendudukan Jepun telah menjadikan masyarakat Melayu terus ditindas oleh penjajah. Pengunduran tentera Jepun bukan bererti tamatnya penderitaan orang Melayu. Kebencian komunis terhadap orang Melayu telah menyebabkan berlakunya kekejaman di serata lokasi di Tanah Melayu. Provokasi dan dendam di antara komuniti Melayu-Cina telah menyebabkan orang Melayu menjadi mangsa kekejaman komunis. Pergaduhan Melayu-Cina yang bermula di Batu Pahat, Johor, sebelum dan selepas pemerintahan Jepun telah menjadi permulaan kepada kekejaman Bintang Tiga. Isu membalas dendam bukan sahaja berlaku di Johor tetapi juga di Sungai Manik, Bekor, Kuala Kangsar, Selangor dan Kuala Lumpur dalam skala yang berbeza. War Office melaporkan banyak kejadian yang melibatkan keganasan bersenjata dan membakar rumah diterima di Johor serta lokasi berhampiran Sungai Perak sejak penghujung Februari 1946.

Pergaduhan Melayu-Cina di negeri Perak berlaku dalam skala besar dan hampir menyeluruh. Kampung Melayu tradisional menjadi sasaran serangan komunis. Orang Melayu telah dituduh bersubahat dalam pembunuhan orang Cina. Kegagalan orang Melayu menjelaskan yuran dan cukai kepada komunis telah mengakibatkan mereka menjadi sasaran balas dendam berikutan pengunduran tentera Jepun. Di Bekor, Kuala Kangsar, Perak, cara penyerangan komunis bermotifkan penghapusan etnik. Orang Melayu dengan semangat keIslaman yang tinggi dan kebencian kepada komunisme telah menjadikan mereka nekad untuk menghalang komunis daripada menguasai tanah air. Tekanan yang melampau menyebabkan orang Melayu bangkit mempertahankan kewujudan dan survival bangsa dengan bersenjatakan parang panjang. Tempoh masa semasa perang ini juga memperlihatkan sebagai "komunis itu Cina, dan Cina itu komunis".

\section{Hubungan Kaum di Kampung Bekor Sebelum Perang}

Dasar campur tangan British telah memberikan implikasi negatif ke atas struktur politik orang Melayu. ${ }^{1}$ Orang Melayu terus menetap di kampung tradisional, komuniti India di ladang getah, manakala orang Cina di kawasan perlombongan dan pinggir bandar. Desakan kehidupan 
menyebabkan berlakunya pergerakan orang Melayu dari satu lokasi ke lokasi yang lain. ${ }^{2}$ Orang Melayu yang terpinggir di kawasan kampung tidak dapat mengikuti arus proses perubahan ekonomi yang diperkenalkan oleh British. Justeru itu, orang Melayu tidak mampu menyediakan tenaga buruh yang dikehendaki oleh pembangunan ekonomi yang diperkenalkan oleh British. Keengganan orang Melayu untuk turut serta sebagai tenaga buruh dalam membantu perkembangan ekonomi British itu telah dijadikan alasan untuk mengambil orang Cina dan India di Tanah Melayu. ${ }^{3}$

Orang Cina telah menggunakan peluang ekonomi yang telah diberikan oleh British dan berjaya meningkatkan diri mereka. Ada di antara mereka yang terlibat secara langsung sebagai pemodal, pemborong, pedagang, perkapalan, lombong bijih dan ladang getah. ${ }^{4}$ Bilangan orang Cina di Tanah Melayu terus meningkat ketika pendudukan Jepun di Tanah Melayu. Antaranya ialah pengambilan seramai 500 orang Cina dari Swatow untuk dijadikan buruh. Seramai 3,497 orang Cina telah dibawa untuk dijadikan buruh bagi tujuan pembinaan Landasan Keretapi Maut Burma-Siam. Seramai 3,000 orang Cina dari Tanah Melayu dan Singapura pula telah dijadikan mekanik dalam pembinaan landasan keretapi maut di Burma. ${ }^{5}$

Menjelang Januari 1946, seramai 3,000 orang Cina telah dibawa dari serata tempat ke Tanah Melayu sebagai memenuhi kewajiban sosial British Military Administration (BMA). ${ }^{6}$ M.E. Doning dari British Foreign Office, yang kemudiannya menjadi Penasihat Politik kepada Laksamana Mountbatten menjelaskan bahawa Kerajaan China telah berunding dengan BMA bagi menempatkan semula pelarian Cina di kawasan Asia Tenggara selepas perang. Orang Cina telah menguasai seluruh kawasan bandar di Tanah Melayu dengan membangunkan kegiatan ekonomi mereka seperti perindustrian, perdagangan dan perniagaan. Pada peringkat awal, sektor yang dinyatakan itu dibangunkan dengan modal Barat. Lama-kelamaan modalnya datang daripada masyarakat Cina sendiri. Kejayaan orang Cina membina kekayaan juga dikaitkan dengan keyakinan dan tujahan yang tepat pada bidang perniagaan dan perdagangan. Kesan daripada itu, berlaku pertukaran sistem nilai budaya masyarakat Cina sehingga mereka meletakkan kekayaan sebagai kriteria utama dalam mengukur status sosial seseorang individu. ${ }^{7}$

Penempatan berdasarkan zon kemakmuran ekonomi telah menyebabkan ketiga-tiga etnik terus terpisah. Imigran Cina dan India berperanan sebagai penjana ekonomi. Sebaliknya orang Melayu yang telah dipinggirkan di kawasan perkampungan diperlukan sebagai pembekal bahan makanan utama. Oleh yang demikian, tidak memungkinkan orang Melayu akan mengalami mobiliti sosial. Sikap prejudis dan prasangka yang sukar dibendung telah berakar umbi dalam kalangan etnik di Tanah Melayu. Sentimen tersebut dipupuk oleh persepsi negatif berkaitan hubungan kaum sejak 1930-an, khususnya semasa dan selepas pendudukan Jepun. Aspirasi politik yang berbeza yang diberikan oleh British kepada orang Melayu dan Cina menyebabkan kedua etnik jauh terpisah.

Balas dendam komunis tidak bercorak individu semata-mata tetapi juga merangkumi ke atas keseluruhan orang Melayu. Oleh yang demikian, serang hendap komunis bermatlamat untuk membunuh orang Melayu sehingga ke peringkat akar umbi. Kenyataan ini terbukti benar di Kampung Bekor, Kuala Kangsar, Perak. Kampung Bekor terletak di tebing kiri atau menghilir ke Sungai Perak dan berada lebih kurang 25.7 Kilometer dari bandar diraja Kuala Kangsar. Kampung ini merupakan sebuah petempatan tradisional yang didiami hampir keseluruhannya oleh orang Melayu. Sebelum Perang Dunia Kedua, Kampung Bekor pernah didiami oleh orang Cina dan India seramai lebih kurang 50 orang. ${ }^{8}$ Kampung Bekor merupakan sebuah petempatan di kawasan tanah rendah di tebing Sungai Perak dan mengandungi beberapa buah perkampungan tradisional kecil seperti Kampung Baru, Kampung Kelang, Kampung Kubang Udang dan 
Kampung Mandah. Perkembangan sosio-ekonomi di Bekor berkait rapat dengan industri perlombongan. ${ }^{9}$

Pada asalnya kawasan tanah lombong ini dikatakan menjadi milik orang Melayu seperti Haji Amin, Uda Jahaya, Anjang Manan dan Uda Muhammad bin Ngah Muhammad. Tanah lombong telah disewakan kepada orang Cina dan mendapat bahagian yang dipanggil sebagai huptong atau sewa. Orang Cina berhijrah dari daerah Kinta dan tinggal di sekitar kongsi Kelian. Kebanyakan orang Cina dari suku Khek bekerja di kawasan perlombongan manakala golongan penoreh getah dan pekebun sayur terdiri dari suku Kongsai. Di kawasan Kampung Bekor terdapat sebanyak 40 buah kedai yang didirikan dalam dua deretan yang memanjang. Orang Cina telah mendominasi sektor pengeluaran bahan makanan dan peruncitan. Walau bagaimanapun, orang Cina tetap mempunyai hubungan akrab dengan penduduk Melayu di Bekor. Antaranya ialah seperti tauke Lee Fan, Sia Kah dan Sia Tin. ${ }^{10}$ Bagi menyediakan pendidikan yang sempurna kepada anak-anak orang Cina, Wei Theik Chinese School telah didirikan di Bekor. ${ }^{11}$ Walau bagaimanapun, sistem pendidikan ketika itu masih berorientasikan negara China. ${ }^{12}$ Sebelum zaman pendudukan Jepun, bilangan rumah orang Melayu dari Kampung Kubang Udang sehingga ke Kampung Kelang dianggarkan berjumlah 150 buah dengan anggaran penduduk seramai 700 ke 800 orang. ${ }^{13}$ Sebagai memenuhi keperluan bahan makanan kebanyakan orang Melayu menanam padi di Kampung Bekor. ${ }^{14}$

Hubungan di antara orang Melayu dan Cina di Kampung Bekor dan sekitarnya berada dalam keadaan harmoni. Dalam keadaan hidup bermasyarakat terdapat beberapa pertelingkahan kecil antara mereka tetapi dapat diselesaikan dengan baik. Keadaan hidup yang harmoni menyebabkan kedua kaum ini hanya memikirkan usaha mencari rezeki dan membina kehidupan yang lebih baik. Orang Melayu terpisah dengan kehidupan mereka yang miskin manakala orang Cina pula bebas dengan budaya hidup mereka yang tersendiri. Perkembangan ekonomi setempat yang menggalakkan telah menyebabkan bilangan kedai yang didirikan di Kampung Bekor dan Kelian meningkat. Walaupun terdapat perbezaan agama dan budaya yang tersendiri, namun kedua-dua kaum masih dapat berurusan dalam keadaan yang harmoni. Menjelang tahun 1930-an hingga 1940-an, berlaku penghijrahan orang Cina dari Bekor dan Kelian ke tempat lain. ${ }^{15}$

\section{Komunis dan Propaganda Jepun}

Keadaan hidup harmoni telah berubah menjadi penuh prasangka sejak zaman pendudukan Jepun. Orang Cina yang seolah-olah sudah tahu mengenai kekalahan pihak British telah mula berpindah ke kawasan pedalaman dan mengusahakan tanaman makanan. ${ }^{16}$ Orang Cina mula menjalankan propaganda mempengaruhi orang Melayu menganggotai kegiatan anti-Jepun. ${ }^{17}$ Pada peringkat awal, ramai orang Melayu di Bekor yang terpengaruh dengan propaganda komunis. Antara pemimpin tempatan dan berpengaruh di Kampung Bekor ialah Harun bin Uda Hassan, Ibrahim bin Ngah Abdul Rahman, Shaharuddin bin Yeop Abdul Hamid dan Yeop Ismail bin Mat Asin. ${ }^{18}$ Malayan People's Anti Japanese Army (MPAJA) atau Bintang Tiga turut menjadikan Bekor sebagai tempat persembunyian dan operasi. Bekor mempunyai laluan selamat ke Sungai Siput yang ketika itu merupakan kawasan utama MPAJA. MPAJA berjaya mempengaruhi sebahagian besar penduduk Bekor untuk menyokong perjuangan mereka. Komunis juga mengenakan cukai terhadap tanaman seperti padi huma yang ditanam oleh penduduk kampung. Pemuda-pemuda Bekor yang patriotik terpengaruh dan mendapatkan latihan dengan MPAJA. MPAJA hanya merupakan pasukan gerila yang mendapat bantuan persenjataan dari British. Pemuda-pemuda ini dihantar ke Sungai Siput untuk mendapat latihan lanjutan. Walau 
bagaimanapun, tidak semua bersetuju dengan ideologi komunis yang dibawa oleh MPAJA. Berikutan perbezaan pendapat dan pertentangan, ramai yang meninggalkan perjuangan mereka.

Menjelang tahun 1945, bilangan anggota Bintang Tiga semakin meningkat. Mereka telah menjadikan kampung terpencil sebagai sasaran. Sekolah Melayu Bekor dijadikan sebagai markas komunis. Komunis telah memaksa penduduk Kampung Bekor mendengar ceramah dan propaganda di Sekolah Melayu Bekor. Guru Besar Sekolah Melayu Bekor ketika itu ialah Cikgu Haji Ahmad bin Monak yang berkhidmat sehingga tahun 1944. ${ }^{19}$ Menjelang tempoh akhir pendudukan Jepun, Bintang Tiga menjalankan kerja sabotaj ke atas papan kenyataan di kawasan Kampung Bekor. Mereka juga melakukan rompakan ke atas kedai orang Cina di pekan Bekor. Kejadian rompakan ini telah didalangi oleh anggota Bintang Satu. Ancaman Bintang Tiga di Kampung Bekor telah menyebabkan pihak pentadbiran Jepun menubuhkan gerakan kawalan kampung yang dikenali sebagai Jikeidan pada bulan Mac 1942. ${ }^{20}$ Walaupun begitu, Jikeidan telah digunakan oleh penduduk Kampung Bekor sebagai ruang menyemarakkan sentimen antiJepun. Kerja merekrut anggota baru Bintang Tiga telah mula dijalankan secara intensif. Ramai belia dari Kampung Bekor diberikan latihan penggunaan senjata. ${ }^{21}$ Pasukan khas yang telah dibentuk dinamakan sebagai hopitoi yang bermaksud askar tambahan.

MPAJA yang mempunyai pengaruh kuat di Bekor telah menjadikan Bekor sebagai pusat pentadbiran bagi daerah Kuala Kangsar. MPAJA telah menjadikan sebuah sekolah di Bekor sebagai pejabat mereka, dan disinilah arahan-arahan dikeluarkan untuk memburu musuh-musuh mereka yang dahulunya penyokong kepada pemerintahan tentera Jepun. Unit-unit pemburu MPAJA ini juga terdiri dari anggota-anggota berbangsa Melayu selain majoritinya orang Cina. Sekolah tersebut juga dijadikan markas operasi untuk menyoal siasat, menyeksa dan membunuh individu yang bersimpati dengan Jepun. ${ }^{22}$

Kesengsaraan penduduk Kampung Bekor telah bermula sejak pendudukan Jepun lagi. Laporan yang telah diberikan oleh ketua Jikeidan mengenai keadaan aman di Bekor telah menimbulkan keraguan kepada pihak Jepun. Seramai sebelas orang penduduk Kampung Bekor telah dipanggil untuk disoal siasat oleh pihak Jepun. Ini diikuti pula oleh kumpulan penduduk kampung yang lain. Kumpulan pertama yang telah dipanggil oleh pihak Jepun ialah Cikgu Haji Ahmad bin Monak, Shaharuddin bin Yeop Abdul Hamid, Alang Ishak, Hamzah bin Ngah Pakar, Mahyuddin, Mat Pora dan Hashim bin Mat Yusuf. Gerakan menyoal penduduk kampung telah diteruskan pada 11 Januari $1944 .^{23}$ Gerakan ini diketuai oleh Sarjan Dahalan, yang dikatakan sebagai tali barut Jepun. ${ }^{24}$ Penduduk Bekor berada dalam keadaan yang amat tertekan kerana mereka berhadapan dengan ancaman Bintang Tiga dan juga Jepun. Dalam hal ini guru-guru yang mengajar di Sekolah Melayu Bekor menjadi sasaran keganasan Bintang Tiga. Kegagalan untuk membuka Sekolah Melayu Bekor ketika perang telah memberikan peluang kepada Bintang Tiga menjadikannya sebagai Ibu Pejabat Batalion ke-13. ${ }^{25}$

Guru Sekolah Kebangsaan Bekor sering kali menjadi mangsa kekejaman Bintang Tiga. Pada 15 Januari 1944, Cikgu Haji Ahmad bin Monak dan Cikgu Haji Jihin bin Chor diserang oleh Bintang Tiga ketika dalam perjalanan ke Sekolah. Kedua-dua mereka telah ditembak oleh Bintang Tiga tetapi berjaya melarikan diri. Cikgu Haji Ahmad bin Monak telah menyelamatkan diri dengan terjun ke dalam Sungai Perak. Cikgu Haji Jihin bin Chor pula telah melarikan diri dengan menggunakan rakit buluh dan menghilir hingga ke Tanjung Belanja. Cikgu Haji Ahmad bin Monak diserang oleh Bintang Tiga kerana keengganannya menyertai gerakan anti-Jepun. Sebelum dipenjarakan di Kuala Kangsar, seorang rakan baiknya yang berbangsa Cina pernah memujuknya menyertai Bintang Tiga. Bintang Tiga juga menaruh dendam kerana beliau telah membuat laporan di Balai Polis Manong mengenai kejadian rumah guru Sekolah Melayu Bekor 
yang telah dirompak oleh mereka. Faktor seterusnya ialah ketika pengumuman pembukaan sekolah pada 14 Januari 1944, Cikgu Haji Ahmad bin Monak telah mengecam dan menyeru penduduk kampung agar tidak menyokong perjuangan komunis atau sebarang gerakan antiJepun.

Komunis juga sering menculik penduduk kampung apabila mereka tidak mahu bekerjasama. Pada kebiasaannya penduduk kampung yang cuba menjalankan usaha mencari akan menemui kegagalan. Kegagalan mencari orang yang hilang akan menerima akibat buruk sekiranya diketahui oleh pihak Jepun. Ini kerana mereka yang hilang, disyaki menjadi kader Bintang Tiga. Beberapa orang penduduk Kampung Bekor yang mempunyai pendirian yang tegas seperti Harun bin Uda Hassan dan Ibrahim bin Ngah Abdul Rahman enggan menyerah diri di Balai Polis Manong atau Kuala Kangsar apabila mereka diarahkan berbuat sedemikian. MPAJA melalui badan dakyahnya telah menggunakan beberapa nama Melayu bagi mendekati penduduk kampung. Antara nama samaran Melayu yang digunakan oleh komunis ialah Kama, Jun dan Zulkifli. Kamal pula berperanan untuk menyampaikan ceramah dan propaganda di Masjid Kampung Bekor. Mereka beranggapan dengan menggunakan nama tersebut akan dapat mendekati penduduk kampung. Terdapat segelintir orang Melayu yang memandang hal ini sebagai satu pengorbanan orang Cina yang seharusnya diberikan penghormatan. Dua orang anggota Badan Dakyah MPAJA iaitu Zulkifli dan Jun memeluk agama Islam dan berkahwin dengan anak penduduk tempatan di Kampung Tepus, Parit, Perak. Selepas kekalahan Jepun, Zulkifli berhijrah ke Medan, Sumatera manakala Jun pula tidak diketahui lokasi tempat tinggalnya. ${ }^{26}$ Pengislaman kedua-dua anggota MPAJA telah memberikan impak positif kepada perjuangan komunis di Bekor. ${ }^{27}$

Sekolah Melayu Bekor bukan sahaja menjadi markas MPAJA, tetapi turut berfungsi sebagai tempat perbicaraan dan melaksanakan hukuman bunuh terhadap penduduk kampung. Komunis melaksanakan hukuman yang tidak logik diterima akal. Di Beruas, Perak, proses pengadilan dijalankan di sebuah padang kecil yang terletak bersebelahan dengan sebuah pasar dan bangunan mahkamah tinggalan British. Bangunan ini kemudiannya dijadikan pusat pentadbiran PKM-TAJRM. ${ }^{28}$ Komunis menubuhkan "Kangaroo Courts" di semua lokasi yang dikuasai oleh mereka dengan matlamat menjatuhkan hukuman kepada penduduk yang disyaki bekerjasama dengan Jepun. ${ }^{29}$ Antara penduduk Kampung Bekor yang menjalankan perbicaraan ialah Shaharudin bin Yeop Abdul Hamid yang akhirnya sinonim dengan panggilan "Din DO”. 30 Sasaran komunis ialah terhadap penduduk Melayu Bekor yang tidak mahu bekerjasama dengan mereka dalam gerakan anti-Jepun ketika zaman perang. Hukuman ke atas pesalah dijalankan di sebuah kawasan berhampiran dengan telaga. Pada kebiasaannya mangsa akan diseksa sebelum dipancung dan dicampakkan ke dalam telaga tersebut. ${ }^{31}$ Ramai penduduk kampung yang menjadi korban seperti Sarjan Dahalan bin Yaakub, Raja Amin, Raja Ehsan, Raja Amran dan Mukhtar bin Ngah Resat. Pesalah yang mempunyai penjamin akan dibebaskan. Namun pada kebiasaannya mereka akan menerima hukuman tanpa siasatan. Beberapa orang ahli aktif Bintang Tiga yang berbangsa Melayu telah mula berpaling tadah. Akhbar Majlis telah melaporkan seperti berikut:

... seluruh Kampung Bekor yang dulunya sangat-sangat menyokong keras akan gerakan kerajaan Bintang Tiga telah ditukarkan tuhan akan perasaan dan rohnya lalu mereka itu berpaling tadah dan mula menentang segala pujukan-pujukan yang mengandungi racun daripada bangsa Cina yang mengajak lagi 
supaya orang Melayu bercampur dengannya untuk menghalau British daripada Semenanjung Tanah Melayu dan kemudiannya Tanah Melayu ini diperintah oleh tiga bangsa ... ${ }^{32}$

\section{Kumpulan Parang Panjang Kampung Bekor}

Dalam usaha mempertahankan kelangsungan survival orang Melayu, golongan ulama, pemimpin agama dan tokoh tempatan memiliki kelebihan luar biasa. Terdapat dua individu yang sering kali dikaitkan dengan amalan mistik dalam masyarakat Melayu iaitu pawang dan bomoh. ${ }^{33}$ Golongan ulama, pemimpin agama dan tempatan telah memainkan peranan penting dan sebagai tempat rujukan bagi mendapatkan pandangan. Golongan pemimpin agama telah memainkan peranan penting dalam menyatupadukan orang Melayu yang terdiri daripada pelbagai suku bangsa. Hal ini bertambah mudah kerana ulama pada peringkat awal terdiri dari pelbagai latar belakang. Terdapat ulama yang berasal dari India, Arab dan juga Indonesia yang berperanan sebagai pencetus semangat juang dalam tempoh masa orang Melayu menghadapi tekanan dan kekejaman komunis. $^{34}$

Kesedaran gerakan nasionalisme, kezaliman komunis dan ketidakseimbangan perencanaan ekonomi, menyebabkan orang Melayu mencari alternatif bagi menyelamatkan nyawa. Hal ini turut ditambah dengan kehilangan kuasa politik sultan dan pembunuhan beberapa orang ulama oleh komunis. British turut melaporkan bahawa amalan ilmu kebal telah bermula pada November 1945 di Negeri Sembilan. Amalan ini tersebar luas ke seluruh Tanah Melayu termasuk di Singapura. ${ }^{35}$ Laporan dari War Office Record turut mengiktiraf bahawa sabilillah telah berjaya menyatukan orang Melayu ketika menghadapi tekanan Bintang Tiga. ${ }^{36}$

Gangguan dan kezaliman komunis telah menyebabkan penduduk Melayu Bekor menubuhkan kumpulan parang panjang. Mereka juga mempelajari ilmu mempertahankan diri seperti pencak silat. Antara tokoh yang menjadi tumpuan dalam mempelajari ilmu pencak silat ialah Ibrahim dan Shaharuddin bin Yeop Abdul Hamid. ${ }^{37}$ Orang Cina juga tidak terkecuali mempelajari kuntau. Ramai guru kuntau yang dikatakan bermastautin di Bekor. Masjid dan surau menjadi tempat penting berkumpul dalam menyatukan penduduk Melayu Kampung Bekor. ${ }^{38}$ Antara pemimpin tempatan yang berpengaruh dalam menyatukan orang Melayu di Bekor ialah Harun bin Uda Hassan. Harun bin Uda Hassan telah mengumpulkan penduduk kampung di surau dan masjid serta memberikan peringatan agar tidak bekerjasama dengan komunis. ${ }^{39}$

Penglibatan beberapa orang ulama tempatan seperti Tuan Haji Salleh bin Abdul Manan, Tuan Haji Abdul Rahman bin Abdul Manan dan Tuan Haji Shahbudin bin Lebai Sulaiman Bakul telah berjaya menyatukan penduduk Melayu di Kampung Bekor. Terdapat juga penglibatan beberapa orang syeikh dari Bagan Serai seperti Tuan Syeikh Osman. Ketika orang Melayu berada dalam keadaan tertekan, seorang syeikh di Bekor telah membawa ilmu cincin kebal dan telah berperanan sebagai penyampai fatwa dalam barisan parang panjang. ${ }^{40}$ Terdapat juga orang Melayu yang menjual gelang lengan kebal bagi melindungi nyawa di kawasan Manong-Bekor. ${ }^{41}$

Selendang merah digunakan bagi meningkatkan semangat perjuangan. ${ }^{42}$ Dalam menjana tenaga dalaman pengamal ilmu kebal, Al-Quran telah menjadi tunjang utama. ${ }^{43}$

Pelbagai cara telah digunakan oleh orang Melayu bagi mempertahankan kelangsungan survival bangsa. Amalan kebal orang Melayu disertai dengan penggunaan beberapa objek seperti tangkal dan susuk jarum emas. Susuk jarum emas pula akan dimasukkan ke dalam pembuluh darah setiap pengamal. Cincin, gelang dan rantai digunakan sebagai azimat pelindung diri ketika menentang komunis. Laporan perisikan British membuktikan bahawa tangkal azimat bagi tujuan perlindungan diri telah dijual oleh orang Melayu di Manong-Bekor. ${ }^{44}$ Cincin tersebut diperbuat 
daripada gelung tembaga dan dipakai bagi tujuan melindungi diri. Cincin kebal ini digunakan secara berleluasa di lokasi berlakunya pergaduhan Melayu-Cina khususnya di Perak. Oleh kerana ulama ini mempunyai ilmu yang tinggi, mereka dengan mudah telah diterima oleh penduduk Kampung Bekor. Pembelajaran ilmu kebal sedikit sebanyak telah menambahkan keyakinan orang Melayu untuk menghadapi tindakan zalim komunis. ${ }^{45}$ Ulama, guru agama dan pemimpin di peringkat tempatan dilaporkan memainkan peranan penting dalam menyebarkan semangat anti-Cina. $^{46}$

Pada pertengahan abad ke-20, ilmu kebal dan kongsi gelap telah digunakan oleh orang Melayu untuk mempertahankan diri. ${ }^{47}$ Bilangan pengamal ilmu kebal ketika tempoh masa ini dianggarkan mencecah angka ribuan orang. ${ }^{48}$ British yang gagal mengawal keadaan, menganggap amalan ilmu kebal orang Melayu mengganggu kestabilan dan keamanan masyarakat. ${ }^{49}$ Hal ini kerana kebergantungan orang Melayu kepada sultan dan juga mufti beralih kepada golongan ulama dan pengamal ilmu kebal. Sumbangan ulama, pemimpin agama dan pemimpin di peringkat tempatan tidak dapat dinafikan dalam memimpin serta menyedarkan masyarakat Melayu ketika diancam oleh komunis. Bilangan mereka tidak dapat dipastikan secara jelas kerana sudah menjadi tradisi dan prinsip ulama silam yang tidak meninggi diri. Oleh yang demikian, ilmu mereka hanya tersebar dalam cakupan ruang yang agak terhad dan di peringkat tempatan. $^{50}$

Dalam tempoh enam bulan pertama selepas Jepun menyerah kalah sudah wujud prasangka negatif dalam kalangan Melayu-Cina. Hal ini kerana, ketika berlaku pergaduhan Melayu-Cina di Sungai Manik, ramai di antara orang Cina dari Bekor yang membantu komunis di lokasi berkenaan. ${ }^{51}$ Peristiwa permusuhan dan penyerangan ke atas orang Melayu telah menyebabkan orang Melayu terus bertindak. ${ }^{52}$ Tambahan pula apabila ulama, pemimpin agama dan pemimpin tempatan Kampung Bekor telah menanamkan semangat jihad serta fisabilillah. Mereka telah mengeluarkan fatwa jihad, di mana sudah menjadi kewajipan orang Islam mempertahankan kampung halaman mereka sekiranya dicerobohi oleh musuh Islam. ${ }^{53}$ Hal seumpama ini telah menyebabkan jiwa masyarakat Melayu menjadi kental dan sebati dengan semangat perjuangan. Hubungan kaum di kawasan Bekor dan Kelian telah mula menjadi renggang. Boleh dikatakan hampir setiap malam kedengaran bunyi tetuang yang digunakan oleh orang Cina untuk berlatih kuntau. ${ }^{54}$

Bibit pergaduhan Melayu-Cina telah bermula pada 2 Januari 1946 yang mengakibatkan seorang Cina terbunuh dan empat yang lain hilang di Bekor. ${ }^{55}$ Civil Adviser Officer (CAO) Kuala Kangsar melawat ke tempat kejadian pada 4 Mac 1946 dan mengadakan perjumpaan dengan pemimpin Melayu serta Cina. Pada malam yang sama, enam buah rumah orang Cina dibakar termasuk Sekolah Cina Bekor. Orang Cina melarikan diri dan mencari perlindungan di Estet Ban Sin Loong. ${ }^{56}$ Dalam satu peristiwa lain, seramai 100 orang Cina telah lari bertempiaran apabila dikejar oleh orang Melayu kerana telah merosakkan tanaman orang Melayu ketika kerja membina jalan kampung selebar enam kaki. Kerja pembinaan tersebut juga telah dijalankan tanpa kebenaran daripada penduduk kampung. Penduduk Melayu berkejar ke tempat kejadian dengan membawa parang panjang dan mengusir pekerja tersebut. ${ }^{57}$

Walau bagaimanapun, terdapat usaha ke arah perdamaian yang telah dilakukan oleh wakil orang Melayu dan Cina. Satu mesyuarat telah diadakan di Manong dengan dihadiri oleh wakil ulama dan pemimpin Cina. Sebanyak tiga tuntutan telah dikemukakan oleh orang Melayu. Tuntutan pertama ialah memulangkan semula orang Melayu yang telah ditangkap dan dibawa ke dalam hutan. Sekiranya mereka ini telah dibunuh, orang Melayu memohon agar ditunjukkan kubur, agar mereka boleh dikebumikan semula mengikut tuntutan agama Islam. Mereka juga 
menuntut kembali harta milik orang Melayu yang telah dirampas oleh komunis. Tuntutan ketiga ialah menyerahkan semua senjata seperti senapang yang berada dalam simpanan mereka kepada pihak kerajaan. ${ }^{58}$

Beberapa mesyuarat di peringkat tempatan juga telah diadakan di antara Ketua Kampung Bekor iaitu Tuan Haji Muhammad Ali dengan wakil orang Cina di Bekor yang dikenali sebagai Ah Foi. ${ }^{59}$ Mesyuarat ini telah diadakan atas inisiatif Tuan Seedwell dan Tuan Catchfold. Punca serangan pada 5 Mac 1946 adalah disebabkan oleh peristiwa pembunuhan seorang Cina. Beberapa orang penduduk Kampung Bekor dikatakan telah menggunakan kesempatan membunuh orang Cina ketika mereka membawa guni padi dari Klian ke Manong. Dalam satu peristiwa yang lain pula beberapa orang penduduk kampung menetak dua orang Cina yang membawa padi ke pekan Manong. Salah seorang daripada mereka terjun ke dalam Sungai Perak yang berhampiran. Manakala seorang lagi sempat melarikan diri. Terdapat juga sumber yang menyatakan bahawa asal mula pergaduhan ialah apabila berlakunya pembunuhan ke atas seorang penduduk Cina yang sedang mengandar ayam di Kampung Bekor. Pembunuhan tersebut dilakukan oleh Kassim bin Alang Mat Yasin. Mayat peniaga tersebut dicampakkan ke dalam sungai dan tersangkut di Sungai Perak. Mayat ini telah dijumpai oleh orang Cina dan mereka mengandar mayat tersebut melalui laluan Kampung Bekor. ${ }^{60}$

\section{Air Mata Bekor 6 Mac 1946}

Serangan komunis di Kampung Bekor berlaku selama dua hari, iaitu selepas hampir sepuluh hari daripada peristiwa orang Melayu membunuh orang Cina. Serangan pertama berlaku pada 5 Mac 1946, hari Selasa jam 10.00 pagi. ${ }^{61}$ Kumpulan ini datang dari arah Klian, Bekor dan Kampung Pauh serta terdiri daripada seramai 100 orang. ${ }^{62}$ Kumpulan penyerang ini dikatakan datang dari dua arah laluan yang berlainan. Dalam perjalanan komunis masuk ke kawasan kampung, mereka telah bertembung di laluan rumah Abdul Rahman bin Uda Mohamad. Kumpulan parang panjang pada pagi itu diketuai oleh Tuan Haji Salleh bin Abdul Manan. Kumpulan komunis dan orang Melayu berada di kawasan kejadian selama hampir dua jam. ${ }^{63}$ Walaupun tidak berlaku pembunuhan, namun dalam serangan pertama pada 5 Mac 1946, sebanyak tujuh buah rumah orang Cina telah dibakar. ${ }^{64}$

Semangat orang Melayu yang tidak mahu menyerah kalah menyebabkan komunis terpaksa berpatah balik dan masuk semula ke kawasan hutan. Tindakan komunis pada pagi itu telah menyebabkan penduduk Kampung Bekor mengadakan mesyuarat tergempar di Masjid Bekor. Mereka membuat keputusan untuk mengadakan pasukan kawalan kampung. Kanakkanak, kaum wanita dan orang tua dikumpulkan di beberapa buah rumah ulama dan juga ketua kampung. Terdapat juga penduduk yang tidur di pondok padi pada waktu malam kerana takutkan komunis. Serangan kali pertama lebih kepada tindakan komunis menguji kekuatan dan persediaan orang Melayu di Bekor. Orang Melayu dengan jelas telah menunjukkan reaksi penentangan dan menolak propaganda komunis. Seorang ulama iaitu Tuan Haji Salleh bin Abdul Manan dikatakan telah mendapat petanda bahawa Kampung Bekor akan diserang dalam tempoh beberapa hari lagi. Oleh yang demikian, beliau telah memberikan semangat untuk mempertahankan kampung halaman mereka.

Bagi memberikan keyakinan kepada penduduk kampung, Tuan Haji Salleh bin Abdul Manan telah memberikan Ayat Empat untuk diamalkan oleh barisan parang panjang Kampung Bekor. Ayat Empat yang menjadi amalan ialah, Laillahailahanta Subhana Ka Inni Kuntum Minazzalimin dan Yazaljalalil Wal Iqram (10 kali), Wallahu Ghalibun Ala’ Amrihi (33 kali), Ya Hayyu Ya Qoyyum Ya ilhana Wa'ilaha kulli Syai'in Ihawahida La'illa Anta (33 kali) dan Ya 
Zaljala Li Wal Ikram. ${ }^{65}$ Antara penduduk kampung yang turut menerima dan mengamalkan ayat tersebut terdiri dari Tuan Haji Shaari bin Haji Amin, Busu Ahmad bin Haji Amin dan Tuan Haji Bashah. Bilangan penduduk kampung yang mengambil dan menghafal ayat tersebut pada malam tersebut dianggarkan seramai tujuh hingga lapan orang sahaja. Walau bagaimanapun, bilangan ini meningkat dari masa ke semasa selepas fatwa jihad fisabilillah dikeluarkan oleh ulama tempatan. $^{66}$

Pada pagi hari Rabu 6 Mac 1946, antara jam $5.00^{67}$ hingga 5.30 pagi telah berlaku serangan kali kedua yang telah dirancang dengan penuh teliti. ${ }^{68}$ Akhbar Majlis melaporkan bahawa bilangan orang Cina yang datang menyerang ialah kira-kira 500 orang dan datang dari daerah Klian. Kumpulan ini telah datang dengan dua puak dan asal tempat kedatangan mereka juga tidak dapat dipastikan, kerana selepas serangan tersebut, mereka telah menghilangkan diri dalam hutan tebal. ${ }^{69}$

Serangan pada 6 Mac 1946 dilakukan pada awal pagi ketika penduduk kampung sedang tidur dan mereka tidak mempunyai kekuatan untuk melawan. ${ }^{70}$ Serangan juga dilakukan secara serentak melalui tiga penjuru. Kumpulan pertama menyerang dari arah Kampung Kelang dan Kampung Teruan/Bekor. Kumpulan kedua dari arah Kampung Baru, manakala kumpulan ketiga dari Kampung Kubang Udang. Setiap kawasan simpang dan jalan utama di seluruh kampung dikawal ketat oleh komunis. Saksi menyatakan bahawa serangan ini telah dilakukan oleh orang Cina yang berkebun sayur di pinggir Kampung Bekor dan Manong. ${ }^{71}$ Dalam serangan tersebut terdapat penglibatan penduduk Cina tempatan yang terdiri daripada guru-guru kuntau. ${ }^{72}$

Menurut maklumat dan pengalaman Tuan Haji Mohd Ali yang telah disampaikan kepada Abdul Rahman bin Uda Mohd, terdapat seramai 15 hingga 20 komunis telah datang ke Kampung Bekor dan mengajak orang Melayu untuk berlawan. ${ }^{73}$ Walau bagaimanapun, dia telah ditangkap dan diikat dengan menggunakan tali. ${ }^{74}$ Beliau mengalami luka kerana ditikam dengan lembing tetapi berjaya melepaskan ikatan dan melarikan diri serta terjun ke dalam sungai untuk menyelamatkan diri. Keadaan kampung yang ketika itu menjadi kelam-kabut telah menyebabkan beberapa orang penduduk yang berada di Masjid Kampung Bekor mengetuk beduk sebagai isyarat kecemasan. Ketukan beduk bukan sahaja dilakukan oleh orang Melayu, tetapi juga oleh kumpulan komunis. ${ }^{75}$ Uda Mohamad bin Malim Elok telah ditikam di bahagian perutnya ketika cuba menyerang komunis dengan menggunakan parang panjang. Manakala rumahnya telah dibakar oleh komunis. $^{76}$

Tokoh yang menjadi tonggak bagi mempertahankan penduduk kampung terdiri daripada Tuan Haji Abdul Rahman bin Abdul Manan, Tuan Haji Salleh bin Abdul Manan, Tuan Haji Kulub Alang dan beberapa orang pemimpin tempatan seperti ketua kampung. Senjata yang digunakan oleh orang Melayu berupa parang panjang, golok dan keris. Manakala komunis menggunakan senapang, serampang, tat dan lembing tat. ${ }^{77}$ Dalam keadaan yang cemas ini, Tuan Haji Shaari bin Haji Amin telah mengarahkan isteri dan anak-anaknya berlindung di rumah. Beliau bersama tujuh hingga lapan orang penduduk kampung turun dan membantu yang lain. Tuan Haji Shaari bin Haji Amin, Daud bin Haji Amin dan abang saudaranya mati ditikam. Tuan Haji Amin bin Kulub Hitam, Abdul Munan bin Haji Amin, dan Tuan Haji Abdul Rahman bin Abdul Manan berada di barisan hadapan. Kesemua mereka telah gugur syahid dalam mempertahankan nyawa penduduk Kampung Bekor. ${ }^{78}$

Keseluruhan petempatan orang Melayu di Bekor telah diserang secara serentak pada 6 Mac 1946. Serangan bukan sahaja dilakukan di tempat awam tetapi melibatkan dari rumah ke rumah. Orang Melayu yang diserang telah mempertahankan ahli keluarga mereka terlebih dahulu sebelum bergabung tenaga membantu yang lain. Keadaan yang terkepung telah menyebabkan 
ramai kanak-kanak dan kaum wanita yang sedang tidur menjadi mangsa. ${ }^{79}$ Kumpulan parang panjang yang diketuai oleh Uda Mohamad bin Malim Elok bersama dengan tiga orang penduduk kampung yang lain menghadapi penyerang seramai beratus-ratus bilangannya. ${ }^{80}$ Selepas hampir sejam mempertahankan keluarga daripada serangan ganas komunis, barulah mereka berpeluang membantu penduduk kampung yang lain. Terdapat juga sebahagian daripada komunis yang berasa kasihan melihat kaum wanita dan kanak-kanak. Oleh yang demikian, mereka hanya membunuh orang lelaki sahaja. ${ }^{81}$

Ketika berlakunya pergaduhan, Abdul Kassim bin Awang Mat Yassin sempat melarikan diri. Kaum wanita Bekor yang sudah sinonim dengan pengetahuan dan pengalaman menggunakan parang panjang, telah menjadi tulang belakang mempertahankan keluarga mereka. Dalam satu kejadian, apabila komunis mengarahkan semua kaum wanita dan kanak-kanak yang berada dalam rumah turun ke bawah, kesempatan telah digunakan oleh Ngah Zabedah binti Sidi menyediakan air bancuhan cili dan menyiram ke muka komunis ketika mereka hendak meluru naik ke dalam rumah. Tindakan ini telah menyebabkan komunis bertambah marah dan mengakibatkan Ngah Zabedah binti Sidi ditikam dengan menggunakan lembing. ${ }^{82}$

Peluang juga telah digunakan khususnya oleh kaum wanita yang lain membawa lari anak-anak mereka yang masih kecil. Ibrahim bin Uda Mohamad telah dibawa lari oleh ibunya melalui kawasan kebun getah dan akhirnya sampai ke pondok persembunyian penduduk kampung. Pada awalnya tempat persembunyian ini agak selamat sehingga akhirnya dapat dikesan oleh komunis. Rumah tersebut telah dibakar dan penduduk yang bersembunyi tidak dapat bertindak kerana dikepung. Salah seorang daripada anggota komunis dikatakan telah membuka pintu rumah dan mengarahkan semua yang bersembunyi turun ke bawah tanpa membawa senjata. ${ }^{83}$

Bagi memastikan keseluruhan penduduk Melayu Kampung Bekor dibunuh, kumpulan komunis di Kampung Kelang telah berjaya memutuskan jambatan di Sungai Bekor. ${ }^{84}$ Ini menyebabkan orang Melayu tidak mendapat bantuan daripada penduduk Kampung Mandah. Keadaan ini juga akan melambatkan pergerakan penduduk kampung yang ingin memberikan bantuan. Strategi penyerangan komunis iaitu dengan membunyikan beduk di masjid telah menyebabkan penduduk kampung berada dalam keadaan kelam-kabut khususnya ketika memberikan bantuan. Taktik ini juga telah menyebabkan orang Melayu tidak dapat berkumpul secara beramai-ramai di sesuatu tempat dan akan memudahkan mereka dibunuh. ${ }^{85}$

Rumah Uda Mashor dijadikan sebagai pusat berkumpul bagi seramai 200 orang perempuan dan kanak-kanak apabila serangan ini berlaku di Kampung Kelang. Kumpulan parang panjang yang mempertahankan serangan di Kampung Kelang terdiri dari Harun bin Uda Hassan, Hashim bin Mohd Yusuf dan Din bin Ngah Abdul Rauf. Kumpulan ini telah menghadapi serangan seramai 20 hingga ke 30 orang komunis yang bersenjatakan lembing. Harun bin Uda Hassan dan Din bin Ngah Abdul Rauf telah ditikam. Mereka telah melarikan diri dan terjun ke dalam sungai. Manakala Hashim bin Mohd Yusuf pula telah beralih mempertahankan serangan di rumah Uda Mashhor. ${ }^{86}$

Isyarat beduk dibunyikan sebagai amaran dan bagi tujuan menimbulkan kekecohan. Di Kampung Kubang Udang, sebelum rumah di bakar, kaum wanita dan kanak-kanak telah diarahkan turun sebelum melarikan diri. Orang lelaki juga dibunuh dan dibakar berserta dengan rumah. Di Kampung Bekor, kesemua isi rumah dibakar hidup-hidup tanpa mengira jantina. ${ }^{87}$ Usaha mendapatkan bantuan juga gagal apabila komunis membakar rumah yang disyaki berpenghuni. Syafie bin Nordin melihat sendiri bagaimana isterinya mati terbakar. Beliau telah melarikan diri untuk meminta bantuan dari penduduk kampung ketika rumahnya dibakar. 
Isterinya yang bernama Fatimah dan anaknya yang bernama Abdul Rahim bin Shafie sedang berlindung dalam rumah. Keadaan api yang mulai marak telah menyebabkan orang Cina turun semula ke bawah rumah. Fatimah berada di belakang api yang sedang marak sambil mendakap anaknya. Anaknya telah berjaya diselamatkan oleh penduduk kampung manakala Fatimah telah mati terbakar. ${ }^{88}$ Serangan ini telah dilaporkan oleh akhbar Majlis bertarikh 5 Mac 1947, “...Mayat Melayu telah terjumpa bergelimpangan esoknya dan 19 buah rumah-rumah termasuk sekolah agama menjadi abu...”89 Manakala akhbar Majlis bertarikh 24 Februari 1947 melaporkan “...Apabila saksi pulang ke rumahnya, didapatinya rumah sudah terbakar, tetapi dia tidak dapat menunjukkan mana satu yang dituduh itu membakar rumahnya..."90

Bilangan rumah yang paling banyak dibakar ialah di Kampung Kubang Udang kerana lokasinya yang agak terpencil. Di Kampung Bekor hanya tiga buah rumah yang dibakar iaitu rumah Ngah Abdul Rauf, sebuah sekolah agama dan rumah Ketua Kampung Bekor iaitu Tuan Haji Mohd Ali. ${ }^{91}$ Walau bagaimanapun, penduduk kampung yang terlibat menyatakan bahawa sebanyak 40 buah rumah telah dibakar oleh komunis. Terdapat beberapa buah rumah yang tidak hangus dijilat api kerana penduduk kampung sempat memadamkan api selepas komunis meninggalkan kawasan tersebut. ${ }^{92}$

\section{Impak Peristiwa 6 Mac 1946}

Serangan komunis pada 6 Mac 1946 telah meninggalkan kesan yang mendalam, khususnya kepada penduduk Melayu di Kampung Bekor. Dalam serangan yang dianggarkan selama dua jam ini, seramai 80 orang Melayu termasuk kanak-kanak telah dibunuh. Terdapat orang Melayu yang dibunuh ketika sedang bersolat subuh di Masjid Kampung Bekor. ${ }^{93}$ Laporan perisikan British menyatakan bahawa seramai 56 hingga 57 orang yang hendak meninggalkan Masjid Bekor selepas solat Subuh dibunuh oleh komunis. ${ }^{94}$ Hanya seorang sahaja yang mempunyai luka tembakan manakala yang lain mempunyai luka ditikam dengan parang dan pisau. ${ }^{95}$ Ramai di antara penduduk kampung yang mengalami kecederaan. Seramai 15 orang lelaki, tujuh wanita dan lapan orang kanak-kanak telah hilang. ${ }^{96}$

Berikutan serangan ini, Senior Civil Adviser Officer (SCAO) telah mengarahkan pasukan keselamatan untuk menjalankan pencarian mangsa dari rumah ke rumah dalam lingkungan jarak lima batu radius (lima kilometer) di kawasan Bekor, Manong dan Parit. ${ }^{97}$ Berikutan serangan tersebut, Tuan Haji Salleh bin Abdul Manan telah gugur syahid ditikam oleh komunis dengan lembing di laluan berhampiran dengan Sekolah Melayu Bekor. Ini diikuti pula oleh kematian Tuan Haji Abdul Rahman bin Abdul Manan dan Tuan Haji Kulub Alang. Ramai orang Melayu yang telah menjadi pelarian berikutan serangan tersebut dan terpaksa mencari perlindungan. ${ }^{98}$ Dianggarkan seramai 100 orang Melayu yang kebanyakannya mengalami kecederaan menjadi pelarian di Kuala Kangsar dan Manong. ${ }^{99}$

Berita serangan komunis pada pagi itu telah sampai ke pengetahuan penduduk Kampung Semat, Manong. ${ }^{100}$ Bunyi ketukan beduk telah memberikan isyarat bahawa sedang berlaku malapetaka dan menjadikan suasana di Kampung Semat menjadi sunyi sepi. ${ }^{101}$ Dalam usaha membantu penduduk kampung, kumpulan parang panjang dari Kampung Semat yang dianggotai oleh Tuan Haji Yop Dun bin Haji Jana, Tuan Haji Mohd Jana bin Nordin, Tuan Haji Khalid, Tuan Haji Dollah dan beberapa orang yang lain bertekad untuk membantu penduduk Kampung Bekor. Pada pagi 7 Mac 1946, jam 9.00 pagi iaitu hari Khamis, dengan bersenjatakan parang panjang, kumpulan ini sampai ke tepi Sungai Perak dengan menaiki sebuah sampan yang besar. Kedatangan mereka disambut oleh komunis dengan bersenjatakan senapang, lembing dan 
lembing tat. Manakala kumpulan orang Melayu hanya bersenjatakan parang panjang dan dua orang lagi memiliki lembing. ${ }^{102}$

Kumpulan ini telah diancam oleh komunis agar meninggalkan kawasan tersebut sebelum dibunuh. Oleh kerana sayangkan nyawa, mereka pulang semula ke Kampung Semat dalam keadaan hampa. Walau bagaimanapun, ramai di antara penduduk Kampung Semat yang telah datang secara berperingkat untuk membantu mangsa di Kampung Bekor walaupun dalam keadaan ketakutan. Ramai di antara mereka yang merawat mangsa yang tercedera dan ada pula yang dibawa pulang ke Kampung Semat dengan menggunakan sampan. Terdapat juga kumpulan yang mencari jenazah penduduk kampung yang telah meninggal dunia dibunuh oleh komunis bagi urusan pengebumian. ${ }^{103}$ Ibrahim bin Uda Mohamad turut serta mencari jenazah bapanya iaitu Uda Mohamad bin Malim Elok. Antara lain yang turut serta dalam kumpulan tersebut ialah Kassim bin Alang Mat Jasin, adik dan abangnya serta beberapa orang penduduk kampung. Pembahagian kerja dilakukan di mana terdapat yang mencari jenazah kaum keluarga mereka, mengumpul jenazah dan ada pula yang menggali liang lahad. ${ }^{104}$

Kebanyakan jenazah kumpulan parang panjang dikebumikan berserta dengan pakaiannya sekali di tempat mereka menemui ajal. Terdapat juga jenazah yang dikebumikan dalam bilangan dua hingga tiga orang dalam satu liang lahad. Jenazah Tuan Haji Salleh bin Abdul Manan dan Tuan Haji Abdul Rahman bin Abdul Manan ditemui dalam keadaan yang masih berdarah. ${ }^{105}$ Kedua-dua ulama ini telah disemadikan dalam satu liang lahad tanpa dimandikan. ${ }^{106}$ Manakala jenazah Uda Mohamad bin Malim Elok, Tuan Haji Derahman dan Anjang Langguk telah dikebumikan bertiga dalam satu liang lahad. Selepas selesai urusan pengebumian jenazah, mereka bersepakat pulang semula ke Kampung Semat kerana takut sekiranya diserang oleh kumpulan komunis lain. ${ }^{107}$

Suatu perkara yang amat menghairankan ialah, walaupun bilangan komunis yang dibunuh oleh orang Melayu dikatakan ramai, namun mayat mereka tidak ditemui oleh penduduk kampung. ${ }^{108}$ Terdapat juga laporan perisikan yang menyatakan bahawa komunis yang terkorban dan cedera dibawa lari oleh anggota mereka yang lain. ${ }^{109}$ Bilangan orang lelaki yang dibunuh adalah lebih ramai jika dibandingkan dengan wanita. Di Kampung Kelang tiada wanita yang dibunuh manakala di Kampung Bekor terdapat enam orang termasuk Rahmah yang mati bersama-sama dengan dua orang anak lelakinya. ${ }^{110}$ Di Kampung Baru kesemua yang mati terdiri daripada kaum lelaki manakala dua orang sahaja yang mati di Kampung Kubang Udang. Serangan yang telah dilakukan oleh komunis jelas menunjukkan bahawa fokus utama penyerang ialah mencari orang lelaki sahaja. Laporan awal yang diterima menyatakan bahawa seramai 22 orang Cina ditahan di Bekor termasuk empat orang Jepun. ${ }^{111}$

Walaupun serangan komunis di Bekor diisytiharkan tamat, namun permusuhan antara orang Melayu dan Cina tetap wujud. Ancaman orang Cina menyebabkan orang Melayu sentiasa bersiap sedia dengan sebarang kemungkinan. Bagi mengawal ketenteraman, tentera telah dihantar oleh British Military Administration (BMA) khususnya ke lokasi yang terlibat. Di samping itu, pemimpin Melayu dan Cina telah membentuk Jawatankuasa Hubungan Antara Kaum bagi mengembalikan semula keharmonian antara Melayu-Cina. ${ }^{112}$ Peristiwa ini juga menyebabkan berlakunya keretakan hubungan Melayu dan Cina. Dalam satu laporan menyatakan bahawa orang Cina yang melakukan serangan di Bekor didalangi oleh enam orang Jepun yang membayar mereka dengan emas. Orang Cina tersebut ditugaskan untuk menimbulkan kekacauan. Di samping itu Orang Asli juga dikatakan membantu komunis melarikan diri ke dalam hutan selepas selesai menyerang kawasan perkampungan Melayu. ${ }^{113}$ 


\section{Kesimpulan}

Tindakan penyerangan komunis adalah bermotifkan balas dendam terhadap orang Melayu yang dikatakan membantu pihak Jepun. Komplot penyerangan ke atas orang Melayu telah dirancang secara teliti oleh komunis. Orang Melayu dituduh berpaling tadah kerana tidak menyokong perjuangan bagi membentuk republik komunis Malaya. Tindakan pertama yang telah dilakukan oleh Bintang Tiga selepas pengunduran tentera Jepun ialah menguasai Balai Polis dan mencari ulama, pemimpin agama serta pemimpin Melayu. Dalam hal ini, pemimpin tempatan yang tidak memberikan kerjasama kepada perjuangan komunis telah menjadi sasaran. Begitu juga mengenai peristiwa serangan di Bekor pada 6 Mac 1946 telah menjadikan bilangan orang Melayu di Kampung Bekor semakin berkurangan. Kejadian pergaduhan Melayu-Cina terus berlarutan di beberapa buah lokasi di Selangor, Kuala Lumpur dan juga Perak yang telah meninggalkan kesan mendalam sama ada ke atas individu atau masyarakat setempat.

Kesan semerta berikutan daripada pergaduhan ini ialah orang Cina tidak berani lagi menetap di kawasan perkampungan Melayu. Ramai di antara mereka yang mula mencari perlindungan di kawasan yang berhampiran dengan pinggir bandar. British pula seolah-olah berpuas hati dengan apa yang berlaku. Hal ini kerana pada peringkat awal, tiada usaha yang dibuat bagi mengekang keadaan tersebut. British hanya bertindak apabila orang Melayu melakukan serangan balas kerana tidak mampu menahan kezaliman komunis. Pada dasarnya kedua-dua kaum mengalami kerugian sama ada kehilangan nyawa, harta-benda dan sebagainya. Hal ini tidak akan timbul sekiranya tiada tekanan dan provokasi yang melampau dikenakan ke atas kedua kaum ini.

\section{Nota}

1 J.A. Furnivall, Netherlands India: A Study of Plural Economy, Cambridge: Cambridge University Press, 1967, hlm. 446.

${ }^{2}$ Khoo Kay Kim, 'Malay Society, 1874-1920s,' Journal of Southeast Asian History, Volume V, No. 2, September 1974, hlm. 183-184.

${ }^{3}$ Mansor Mohd. Noor, Abdul Rahman Abdul Aziz, Mohamad Ainuddin Iskandar Lee, Hubungan Etnik di Malaysia, Selangor: Pearson Malaysia Sdn. Bhd., 2006, hlm. 84.

${ }^{4}$ Rupert Emerson., Malaysia: A Study in Direct and Indirect Rules, Kuala Lumpur: University Malaya Press, 1937/1966, hlm. 478.

${ }^{5}$ MU. SEC. 1493/46 (4), Wu Paak-Shing, Consul-General, Consulate General Of The Republic Of China, Singapore kepada The Chief Secretary, The Secretariat, Government of The Malayan Union, Kuala Lumpur, 8 Julai 1946.

${ }^{6}$ MU. SEC. 1493/46 (3), Memorandum On The General Position Of Externally Displaced Overseas Chinese.

${ }^{7}$ Mansor Mohd. Noor, Abdul Rahman Abdul Aziz, Mohamad Ainuddin Iskandar Lee, Hubungan Etnik, hlm. 59.

${ }^{8}$ Buyong Adil, Sejarah Perak, Kuala Lumpur: Dewan Bahasa dan Pustaka, 1972, hlm. 3. Lihat juga wawancara dengan Abdul Rahman bin Uda Mohamad di Kampung Kubang Udang, Bekor, Kuala Kangsar, 20 November 2008.

${ }^{9}$ Kamaruddin bin Mohd Piah, 'Kampong Bekor Sejak 1900, Satu kajian Sejarah Tempatan dengan Rujukan Khas Kepada Trajedi 6 hb: Mac 1946,’ Latihan Ilmiah, Jabatan Sejarah, Universiti Malaya, 1974/1975, hlm. 19.

${ }^{10}$ Wawancara dengan Tuan Haji Abdul Aziz bin Shaari di Kampung Kubang Udang, Bekor, Kuala Kangsar, Perak, 20 November 2008.

${ }^{11}$ Kamaruddin bin Mohd Piah, 'Kampong Bekor,' hlm. 26. 
${ }^{12}$ Victor Purcell, The Chinese In Modern Malaya, Singapore: Donald Moore, 1956, hlm. 222-234. Lihat juga wawancara dengan Tuan Haji Abdul Aziz bin Shaari.

${ }^{13}$ Kamaruddin bin Mohd Piah, 'Kampong Bekor,' hlm. 28. Lihat juga wawancara dengan Abdul Rahman bin Uda Mohamad.

${ }^{14}$ Wawancara dengan Tuan Haji Abdul Aziz bin Shaari.

${ }^{15}$ Ibid.

${ }^{16}$ Wawancara dengan Abdul Rahman bin Uda Mohd.

${ }^{17}$ Wawancara dengan Tuan Haji Abdullah Halim bin Mohd Jana di Kampung Semat, Manong, Perak, 21 November 2008.

${ }^{18}$ Kamaruddin bin Mohd Piah, 'Kampong Bekor,’ hlm. 48.

${ }^{19}$ Wawancara dengan Tuan Haji Abdul Aziz bin Shaari. Lihat juga wawancara dengan Tuan Haji Abdul Kadir bin Haji Bakri di Parit 8 B, Sungai Manik, Perak, 5 Jun 2008.

${ }^{20}$ Chin Kee Onn, Malaya Upside Down, Singapore: Jitts \& Co., 1946, hlm. 113.

${ }^{21}$ Kamaruddin bin Mohd Piah, 'Kampong Bekor,' hlm. 51.

${ }^{22} \mathrm{http} / / /$ konflikdanmiliter.blogspot.my/2014/11/bekor-tragedy-5-march-1946-105.html.

${ }^{23}$ Kamaruddin bin Mohd Piah, ‘Kampong Bekor,’hlm. 54.

${ }^{24}$ Wawancara dengan Tuan Haji Abdul Kadir bin Abdul Rahman di Kampung Kubang Udang, Bekor, Kuala Kangsar, Perak, 20 November 2008.

${ }^{25}$ Wawancara dengan Tuan Haji Abdul Aziz bin Shaari.

${ }^{26}$ WO 203/5302 (2), Malaya's Political Climate III, Period October $19^{\text {th }}$ to November $9^{\text {th }} 1945$, (TOP SECRET).

${ }^{27}$ Wawancara dengan Abdul Rahman bin Uda Mohd.

${ }^{28}$ Ahmad Zaki bin Mohd Johari, 'Kegiatan Parti Komunis Malaya Di Pantai Remis-Beruas, 1945-1948: Kajian Berasaskan Sumber Lisan’, Disertasi Sarjana, Jabatan Sejarah, Universiti Malaya, 2011, hlm. 47.

${ }^{29}$ J.J. Raj (JR), The Struggle For Malaysian Independence, Kuala Lumpur: MPH Group Publishing Sdn. Bhd, 2007, hlm. 58.

${ }^{30}$ Kamaruddin bin Mohd Piah, 'Kampong Bekor,' hlm. 52. Lihat juga wawancara dengan Abdul Rahman bin Uda Mohd.

${ }^{31}$ WO 172/1797 (441), War Diary, HQ Malaya Command kepada SACSEA ALFSEA, ISUM NO. 59. Lihat juga wawancara dengan Abdul Rahman bin Uda Mohd.

${ }^{32}$ Majlis, 17 Februari 1947.

${ }^{33}$ Kirk Micheal Endicott, An Analysis of Malay Magic, Oxford: Clarendon Press, 1970, hlm. 13-15.

${ }^{34}$ Wawancara dengan Tuan Haji Ali Badron bin Haji Sabor di Surau Jalan Omar, Batu Pahat, Johor, 22 Oktober 2012.

${ }^{35}$ CO 537/1583 (11), Defence Security Officer (Malayan Union) kepada H.E. The Governor, Malayan Union, 7 Oktober 1946 (SECRET).

${ }^{36}$ WO 172/9773 (162), SECRET, War Diary Of, H.Q. Malaya Command, Intelligence Summary No. 14, Based On Information Received Up To 2 February 1946.

${ }^{37}$ Kamaruddin bin Mohd Piah, 'Kampong Bekor,' hlm. 66.

${ }^{38}$ Wawancara dengan Tuan Haji Abdul Aziz bin Shaari.

${ }^{39}$ Dalam akhbar Majlis dinyatakan “... antara orang Melayu di Kampung Bekor yang ditakuti ialah Harun dan beberapa orang kawan-kawannya”. Lihat Majlis, 17 Februari 1947.

${ }^{40}$ Wawancara dengan Abdul Rahman bin Uda Mohd.

${ }^{41}$ WO 172/9773 (688), SECRET, War Diary Of, H.Q. Malaya Command, Message Form From Hq Malaya Command To ALFSEA, Date Too 22/610. Lihat juga wawancara dengan Ibrahim bin Uda Mohd di Kampung Suak Petai, Manong, Perak, 21 November 2008.

${ }^{42}$ CO 537/1583 (11), Defence Security Officer (Malayan Union) kepada H.E., The Governor, Malayan Union (SECRET), Sabilillah and "Invulnerebility", 7 Oktober 1946.

${ }^{43}$ WO 172/9773 (161), SECRET, War Diary Of, H.Q. Malaya Command, Intelligence Summary No. 14, Based On Information Received Up To 2 February 1946.

${ }^{44}$ WO 172/9773 (161), SECRET, War Diary Of, H.Q. Malaya Command, Intelligence Summary No. 14, Based On Information Received Up To 2 February 1946. Lihat juga CO 537/1583 (11), Defence Security Officer (Malayan Union) kepada H.E. The Governor, Malayan Union (SECRET), Sabilillah and "Invulnerebility", 7 Oktober 1946.

${ }^{45}$ WO 172/9773 (366), SECRET, War Diary Of, H.Q. Malaya Command, Weekly Intelligence Review, No. 22, Week Ending 30 March 1946. 
${ }^{46}$ WO 172/9773 (70), SECRET, War Diary Of, H.Q. Malaya Command, Message Form From Hq Malaya Command To SACSEA , ALFSEA.

${ }^{47}$ Mingguan Malaysia, 25 Disember 2011.

${ }^{48}$ CO 537/1583 (11), Defence Security Officer (Malayan Union) kepada H.E., The Governor, Malayan Union (SECRET), Sabilillah and "Invulnerebility", 7 Oktober 1946.

${ }^{49}$ CO 537/1583 (2), Edward Gent kepada J.J. Paskin, 8 Oktober 1946.

50 Ismail Che Daud, Tokoh-tokoh Ulama' Semenanjung Melayu (2), Kota Bharu: Nivea Enterprise, 2007, hlm., Lampiran IV.

${ }^{51}$ Wawancara dengan Tuan Haji Yop Dun bin Haji Jana di Kampung Semat, Manong, Perak, 21 November 2008.

${ }^{52}$ Wawancara dengan Abdul Rahman bin Uda Mohamad.

${ }^{53}$ Lihat wawancara dengan Tuan Haji Abd. Aziz bin Shaari.

${ }^{54}$ WO 172/1796 (428), War Diary, 2 January 1946.

${ }^{55}$ WO 203/2660 (49), Malaya Command Of Sitreps Up To 1700 Hrs 2 Jan 46 (SECRET).

${ }^{56}$ BMA Secretariat PR/3/2-Part III (14), Kin Kwok Daily News, 8 Mac 1946.

${ }^{57}$ Seruan Ra'ayat, 7 Januari 1946, hlm. 1.

${ }^{58}$ Ibid.

${ }^{59}$ Kamaruddin bin Mohd Piah, ‘Kampong Bekor,' hlm. 95.

${ }^{60}$ Wawancara dengan Abdul Rahman bin Uda Mohamad.

${ }^{61}$ Kamaruddin bin Mohd Piah, 'Kampong Bekor,' hlm. 90. Lihat juga wawancara dengan Tuan Haji Abdul Aziz bin Shaari.

${ }^{62}$ WO 172/9773 (281), SECRET, War Diary Of, H.Q. Malaya Command, 1946, Message Form From Hq Malaya Command To SACSEA, ALFSEA, DTO0 07. Lihat juga wawancara dengan Abdul Rahman bin Uda Mohammad.

${ }^{63}$ Kamaruddin bin Mohd Piah, 'Kampong Bekor,' hlm. 90.

${ }^{64}$ WO 172/9773 (234), SECRET, War Diary Of, H.Q. Malaya Command, Weekly Intelligence Review, No. 19, Week Ending 9 March 1946.

${ }^{65}$ Siti Patonah Muashot, 'Penghulu, Panglima, Kiayi Salleh bin Abd. Karim', dalam Abu Bakar A. Hamid, Md. Ismail Zamzam, Kamdi Kamil (editor), Johor Mengenang Sumbangsihmu, Johor Bahru: Yayasan Warisan Johor, 2006, hlm. 121-122.

${ }^{66}$ Wawancara dengan Tuan Haji Abdul Aziz bin Shaari.

${ }^{67}$ WO 172/9773 (281), SECRET, War Diary Of, H.Q. Malaya Command, 1946, Message Form From Hq Malaya Command To SACSEA , ALFSEA, DTO0 07.

${ }^{68}$ CO 537/1580 (21), Cypher Telegram From Headquarters, B.M.A. (M) To 3, Of S., Colonies, 7 Mac 1946.

${ }^{69}$ CO 537/1580 (17-18), H. R. Hone kepada Consul-General, Consulate-General of The Republic of China, Singapore, 8 Mac 1946. Lihat juga wawancara dengan Abdul Rahman bin Uda Mohd.

${ }^{70}$ Wawancara dengan Tuan Haji Abdullah Halim bin Mohd Jana.

${ }^{71}$ Wawancara dengan Ibrahim bin Uda Mohd.

${ }^{72}$ Wawancara dengan Tuan Haji Abdul Aziz bin Shaari.

${ }^{73}$ Wawancara dengan Abdul Rahman bin Uda Mohd.

${ }^{74}$ Majlis, 24 Februari 1947.

${ }^{75}$ Wawancara dengan Tuan Haji Abdul Aziz bin Shaari.

${ }^{76}$ Wawancara dengan Abdul Rahman bin Uda Mohamad.

${ }^{77}$ Ibid.

${ }^{78}$ Wawancara dengan Tuan Haji Abdul Aziz bin Shaari.

${ }^{79}$ Utusan Melayu, 12 Mac 1946.

${ }^{80}$ Wawancara dengan Abdul Rahman bin Uda Mohd.

${ }^{81}$ Wawancara dengan Tuan Haji Abdul Aziz bin Shaari.

${ }^{82}$ Wawancara dengan Tuan Haji Yop Dun bin Haji Jana

${ }^{83}$ Wawancara dengan Ibrahim bin Uda Mohd.

${ }^{84}$ Kamaruddin bin Mohd Piah, 'Kampong Bekor,' hlm. 80.

${ }^{85}$ Wawancara dengan Tuan Haji Yop Dun bin Haji Jana.

${ }^{86}$ Wawancara dengan Tuan Haji Abdul Aziz bin Shaari. Lihat juga Kamaruddin bin Mohd Piah, 'Kampong Bekor,' hlm. 80.

${ }^{87}$ Wawancara dengan Abdul Rahman bin Uda Mohamad.

${ }^{88}$ Wawancara dengan Tuan Haji Abdullah Halim bin Mohd Jana.

${ }^{89}$ Majlis, 5 Mac 1947. 
${ }^{90}$ Majlis, 24 Februari 1947.

${ }^{91}$ Kamaruddin bin Mohd Piah, 'Kampong Bekor,' hlm. 84.

${ }^{92}$ Wawancara dengan Tuan Haji Yop Dun bin Haji Jana.

${ }^{93}$ Wawancara dengan Tuan Haji Abdul Aziz bin Shaari.

${ }^{94}$ WO 172/9773 (234-235), SECRET, War Diary Of, H.Q. Malaya Command, Weekly Intelligence Review, No. 19, Week Ending 9 March 1946.

${ }_{95}$ WO 172/9773 (252), SECRET, War Diary Of, H.Q. Malaya Command, Weekly Intelligence Review, No. 21, Week Ending 23 March 1946.

${ }^{96}$ WO 172/9773 (286), SECRET, War Diary Of, H.Q. Malaya Command, 1946, Message Form From Hq Malaya Command To SACSEA , ALFSEA, DTOO 11/745 GH. Lihat juga wawancara dengan Tuan Haji Abdullah Halim bin Mohd Jana.

${ }^{97}$ WO 172/9773 (286), SECRET, War Diary Of, H.Q. Malaya Command, 1946, Message Form From Hq Malaya Command To SACSEA, ALFSEA, DTOO 11/745 GH.

${ }^{98}$ WO 172/9773 (235), SECRET, War Diary Of, H.Q. Malaya Command, Weekly Intelligence Review, No. 19, Week Ending 9 March 1946.

${ }^{99}$ WO 172/9773 (281), SECRET, War Diary Of, H.Q. Malaya Command, 1946, Message Form From Hq Malaya Command To SACSEA , ALFSEA, DTO0 07.

${ }^{100}$ Wawancara dengan Tuan Haji Yop Dun bin Haji Jana.

${ }^{101}$ Wawancara dengan Tuan Haji Abdullah Halim bin Mohd Jana.

${ }^{102}$ Wawancara dengan Tuan Haji Yop Dun bin Haji Jana.

${ }^{103}$ Wawancara dengan Tuan Haji Abdullah Halim bin Mohd Jana.

${ }^{104}$ Wawancara dengan Ibrahim bin Uda Mohamad.

${ }^{105}$ Wawancara dengan Tuan Haji Yop Dun bin Haji Jana.

${ }^{106}$ Wawancara dengan Tuan Haji Abdullah Halim bin Mohamad Jana.

${ }^{107}$ Wawancara dengan Ibrahim bin Uda Mohamad.

${ }^{108}$ WO 172/9773 (92), SECRET, War Diary Of, H.Q. Malaya Command, Message Form From Hq Malaya Command To SACSEA, ALFSEA, DT00 10.

${ }^{109}$ WO 172/9773 (235), SECRET, War Diary Of, H.Q. Malaya Command, Weekly Intelligence Review, No. 19, Week Ending 9 March 1946.

${ }^{110}$ Wawancara dengan Abdul Aziz bin Shaari.

${ }^{111}$ WO 172/9773 (251), SECRET War Diary Of, H.Q. Malaya Command, Weekly Intelligence Review, No. 21, Week Ending 23 March 1946.

${ }^{112}$ CO 537/1580 (21), Cypher Telegram From Headquarters, B.M.A. (M) To 3, Of S., Colonies, 7 Mac 1946.

${ }^{113}$ BMA PR/3/6/(S) (38A), Daily Press Summary-K.L. Vernacular Press, 13 Mac 1946. 